\title{
The Effect of the Tool Wear on the Correlation of Forces on the Face and Flank Surfaces of the Cutting Tool
}

Sergei Babak, Alexey Popov

Department of Machining and Assembly, Faculty of Mechanical Engineering, Technical University of Liberec. 461 17, Studentská 1402/2, Liberec 1, Czech Republic.

E-mail: babakss@mail.ru, alespopov@yandex.ru

\begin{abstract}
A new comparison method of the total forces for different contact areas has been published which allows increasing determination accuracy for cutting forces on flank surface. In this regard, on the basis of the new method the laboratory of the Department of Machining and Assembly of the Technical University of Liberec has carried out a study to determine the effect of tool wear on the correlation of forces on the face and flank surfaces of the cutting tool when cutting various materials.
\end{abstract}

Keywords: Machining, Cutting force, Wear

\section{Acknowledgments}

This article is related to the investigation on the Specific University Research Projects which are supported by the Ministry of Education (MSMT) of the Czech Republic.

\section{References}

[1] ZOREV, N. (1966). Metal cutting mechanics. In: Pergamon Press, Oxford. Pp. 135-180.

[2] WYEN, C., WEGENER, K., ZYUST, R. (2010). Influence of cutting edge radius on cutting forces in machining titanium. In: Annals of the CIRP. Vol. 59 (1), pp. 89-92.

[3] WU, X., LI, L., HE, N., HAO, X., YAO, C., ZHONG, L. (2016). Investigation on the ploughing force in microcutting considering the cutting edge radius. In: International Journal of Advanced Manufacturing Technology. Vol. 86 (9-12), pp. 2441-2447.

[4] WU, X., LI, L., HE, N., YAO, C., ZHAO, M. (2016). Influence of the cutting edge radius and the material grain size on the cutting force in micro cutting. In: Precision Engineering. Vol. 45, pp. 359-364.

[5] PIMENOV, D.Y., GUZEEV, V.I. (2016). Mathematical model of plowing forces to account for flank wear using FME modeling for orthogonal cutting scheme. In: International Journal of Advanced Manufacturing Technology. Pp. 1-11.

[6] GUZEEV, V.I., PIMENOV, D.Y. (2011). Cutting force in face milling with tool wear. In: Russian Engineering Research. Vol. 31 (10), pp. 989-993.

[7] JERSAK, J., KAPLAN, F. (2015). Comparison of the influence of process fluids on tool life in face milling. In: Manufacturing Technology. Vol. 15 (6), pp. 977-984.

[8] NAPRSTKOV, N., CAIS, J., STANCEKOVA, D. (2014). Influence of Alsi7Mg0.3 alloy modification by Sb on the tool wear. In: Manufacturing Technology. Vol. 14 (1), pp. 75-79.

[9] VASILKO, K., MURČINKOVÁ, Z. (2016). Tool life extension methods for cut-off tools made of high-speed steel. In: Procedia Engineering. Vol. 149, pp. 520-525.

[10] POPOV, A., DUGIN, A. (2014). Effect of uncut chip thickness on the ploughing force in orthogonal cutting. In: International Journal of Advanced Manufacturing Technology. Vol. 76 (9-12), pp. 1937-1945.

[11] POPOV, A., DUGIN, A. (2014). Study of reasons of increased active force using coolant with uncut chip thickness. In: International Journal of Advanced Manufacturing Technology. Vol. 70 (9-12), pp. 1555-1562.

[12] POPOV, A., DUGIN, A. (2013). Influence of lubricant and coolant fluid on the cutting force in small-increment planning. In: Russian Engineering Research. Vol. 33 (2), pp. 84-85.

[13] DUGIN, A., POPOV, A. (2012). Effect of the processing materials on the ploughing force values. In: Manufacturing Technology. Vol. 12 (13), pp. 102-105.

[14] POPOV, A., DUGIN, A. (2012). Experimental methods of determining the cutting forces at the tool's rear surface. In: Russian Engineering Research. Vol. 32 (1), pp. 68-69.

[15] COLWELL, L. (1970). Methods for sensing the rate of tool wear. In: Annals of the CIRP. Vol. 19 (4), pp. 647651. 